\title{
PHRASEOLOGICAL UNITS AS MEANS OF EXPRESSING THE EMOTIVITY IN THE TATAR LANGUAGE
}

\author{
UNIDADES FRASEOLÓGICAS COMO MEIO DE EXPRESS ÃO DA EMOTIVIDADE NA \\ LÍNGUATARTARA
}

\section{UNIDADES FRASEOLÓGICAS COMO MEDIO DE EXPRESAR LA EMOTIVIDAD EN EL LENGUAJE TATAR}

\author{
Gulshat Raisovna GALIULLINA ${ }^{1}$ \\ Gulfiya Kamilovna KHADIEVA ${ }^{2}$ \\ Zilya Mullakhmetovna MUKHAMETGALIEVA ${ }^{3}$ \\ Margarita Emilievna DUBROVINA ${ }^{4}$
}

\begin{abstract}
Systematization and description of the arsenal of linguistic means of expressing emotions represent one of the major tasks for linguistics that returns nowadays to the theory of Wilhelm von Humboldt, which in the early XIXth century appealed to study the language in close connection with individual speakers. A logical interest of the researchers to the processes of manifestation of emotions in the language has resulted in the formation of a new scientific field - linguistics of emotions aimed at the emotional environment of the language. In the Tatar language human emotions are verbalized mostly by the phraseological units representing various mental states of a person, one's inner world. Studying means of expressing emotive vocabulary illustrated by the phraseological units provides an opportunity to present the whole complex of means of the language and the speech, as well as contribute to understanding the mentality and psychology of a Tatar language person. This article covers the Tatar phraseological units expressing negative connotation. The theme group "anger" represents the object of research. The authors have studied the emotional and appraisal semantics of the given group of phraseological units and attempted the revealing the specificity of the way of thinking and the worldview of the Tatar people. The analysis revealed that the phraseological units of the studied group are characterized by a great diversity of lexical, semantic, emotional and appraisal aspects. The emotional and appraisal volume of the phraseological units varies depending on the emotional state of the speaker and on his attitude to the addressee. Cultural and connotative semantics of the phraseological units is closely connected to the Tatar people's worldview which has formed and has been enriched throughout the life experience.
\end{abstract}

KEYWORDS: Tatar language. Emotional vocabulary. Phraseological units. Culture. Ethnopsychology.

${ }^{1}$ Kazan Federal University (KPFU), Kazan - Russia. Professor of the Department of Tatar Linguistics, Institute of Philology and Intercultural Communication. Doctor of Philology. ORCID: https://orcid.org/0000-0001-69232190. E-mail: caliullina@list.ru

${ }^{2}$ Kazan Federal University (KPFU), Kazan - Russia. Associate Professor of the Department of Tatar Linguistics, Institute of Philology and Intercultural Communication. Candidate of Philology. ORCID: https://orcid.org/00000001-5316-4947. E-mail: gul-khadieva@yandex.ru

${ }^{3}$ Kazan Federal University (KPFU), Kazan - Russia. Postgraduate Student of the Department of Tatar Linguistics, Institute of Philology and Intercultural Communication. ORCID: https://orcid.org/0000-0001-5763-6227. E-mail: zilyu@mail.ru

${ }^{4}$ Saint Petersburg State University (SPBU), Saint Petersburg - Russia. Associate Professor of the Department of Turkic Philology, Faculty of Oriental Studies, St Petersburg University. Candidate of Philology. ORCID: https://orcid.org/0000-0002-7170-6217. E-mail: maggydu@rambler.ru

Rev. EntreLínguas, Araraquara, v. 7, n esp. 1, p. 154-161, fev. 2021. 
RESUMO: A sistematização e a descrição do arsenal de meios linguísticos de expressão de emoções representam uma das principais tarefas da linguística que retorna hoje à teoria de Wilhelm von Humboldt, que no início do século XIX apelava ao estudo da língua em estreita ligação com falantes individuais. Um interesse lógico dos pesquisadores pelos processos de manifestação das emoções na língua resultou na formação de um novo campo científico - a linguística das emoções voltadas para o ambiente emocional da língua. Na linguagem tártara, as emoções humanas são verbalizadas principalmente pelas unidades fraseológicas que representam vários estados mentais de uma pessoa, seu mundo interior. O estudo dos meios de expressão do vocabulário emotivo ilustrado pelas unidades fraseológicas oferece uma oportunidade de apresentar todo o complexo de meios da linguagem e da fala, além de contribuir para a compreensão da mentalidade e da psicologia de uma pessoa da língua tártara. Este artigo cobre as unidades fraseológicas tártaras que expressam conotação negativa. O grupo temático "raiva" representa o objeto de pesquisa. Os autores estudaram a semântica emocional e de avaliação de um determinado grupo de unidades fraseológicas e tentaram revelar a especificidade do modo de pensar e da visão de mundo do povo tártaro. A análise revelou que as unidades fraseológicas do grupo estudado são caracterizadas por uma grande diversidade de aspectos lexicais, semânticos, emocionais e avaliativos. $O$ volume emocional e de avaliação das unidades fraseológicas varia dependendo do estado emocional do falante e de sua atitude para com o destinatário. A semântica cultural e conotativa das unidades fraseológicas está intimamente ligada à visão de mundo do povo tártaro, que se formou e foi enriquecida ao longo da experiência de vida.

PALAVRAS-CHAVE: Língua tártara. Vocabulário emocional. Unidades fraseológicas. Cultura. Etnopsicologia.

RESUMEN: La sistematización y descripción del arsenal de medios lingüisticos de expresión de emociones representa una de las principales tareas de la lingüistica que retorna hoy en día a la teoría de Wilhelm von Humboldt, que a principios del siglo XIX apelaba al estudio de la lengua en estrecha relación con hablantes individuales. . Un interés lógico de los investigadores por los procesos de manifestación de las emociones en el lenguaje ha dado lugar a la formación de un nuevo campo científico: la lingüística de las emociones dirigida al entorno emocional del lenguaje. En el lenguaje tártaro, las emociones humanas se verbalizan principalmente mediante las unidades fraseológicas que representan varios estados mentales de una persona, el mundo interior de una persona. El estudio de los medios para expresar el vocabulario emotivo ilustrado por las unidades fraseológicas brinda la oportunidad de presentar todo el complejo de medios del lenguaje y el habla, además de contribuir a comprender la mentalidad y psicología de una persona que habla tártaro. Este artículo cubre las unidades fraseológicas tártaras que expresan una connotación negativa. El grupo temático "ira" representa el objeto de investigación. Los autores han estudiado la semántica emocional $y$ de valoración del grupo dado de unidades fraseológicas y han intentado revelar la especificidad de la forma de pensar y la cosmovisión del pueblo tártaro. El análisis reveló que las unidades fraseológicas del grupo estudiado se caracterizan por una gran diversidad de aspectos léxicos, semánticos, emocionales y valorativos. El volumen emocional y de valoración de las unidades fraseológicas varía en función del estado emocional del hablante y de su actitud hacia el destinatario. La semántica cultural y connotativa de las unidades fraseológicas está estrechamente relacionada con la cosmovisión del pueblo tártaro, que se ha formado y se ha enriquecido a lo largo de la experiencia de vida. 
PALABRAS CLAVE: Lengua tártara. Vocabulario emocional. Unidades fraseológicas. Cultura. Etnopsicología.

\section{Introduction}

The language of every people has figures of speech, word expressions which reflect the national tint of the language. Among language units expressing the way of thinking of an ethnos phraseological units hold a special place. The majority of phraseological units possess the property of expressing emotivity.

An emotion is commonly perceived as feelings, mental disturbance. In psychology, emotions are defined as experiences connected with a person's assessment of importance of the factors affecting him and expressed in particular in the form of related feelings, satisfaction and non-satisfaction of his expecting needs. Emotions form an important component of a person's state, reflect his inner world, and the outer manifestation of emotions is a person's speech and physical condition.

In human sciences, a person's emotional sphere is the object of phycologists, philosophers and linguists' research. The modern trends in linguistics have led to formation of new fields studying emotions: sociolinguistics, cognitology, psycholinguistics, linguostylistics. Despite an increase in research of pragmatic aspects and means of expression of emotions both in domestic and foreign linguistics, this aspect has hardly been paid any attention by the researchers. Nevertheless, some aspects of the problem in question have been highlighted in the works devoted to other linguistic issues. Thus, linguistic and stylistic aspects of expressing emotions in various levels of the language were highlighted in the works by D.K. Vakhitova (VAKHITOVA， 2013). G.Z. Gabbasova (GABBASOVA， 2002). G.R. Galliullina (GALIULlinA, ET AL. 2001).“N.F. Galieva ,(GALIEVA; GALIULlinA, 2015). A.K. Gizatullina (GIZATULLINA, 2001). I.K. Yerbulatova (YERBULATOVA; KIRILLOVA; SAHIN, 2019). M.Z. Zakiev (ZAKIEV, 2015).“ Kh.Kh. Kuzmina (KUZMINA; KHADIEVA; GALIULLINA，2019). A.A. Abdrakhmanova (ABDRAKHMANOVA; GALIULLINA; KHADIEVA, 2017). T.S. Shcherbinina (SHCHERBININA; DENMUKHAMETOVA; DENMUKHAMETOV, 2016). and others. The linguo-culturological aspect of expressing emotions in the Tatar linguistics was the objective of works by L.K. Bayramova (BAYRAMOVA, 2012). R.R. Zamaletdinov (ZAMALETDINOV, 2012). and others. 
The relevance of the research is the result of the lack of studies on emotivity in the modern Tatar linguistics as well as on the specificity of expressing a person's emotional state by means of phraseological units.

The work is aimed at the analysis of the phraseological units of the theme group "anger" and revealing the specific features of the national view of the world and the way of thinking of the Tatar people reflected in the studied lexical units.

The information represented in this article is assumed to be of interest for researchers dealing with the issues in linguistics, linguoculturology and ethnoculturology and studying the history of the Tatar language as well as the language contact.

\section{Methods}

The research included a complex of methods and techniques which allowed to get the major results. By means of the descriptive method the analysis of the scientific-theoretical and practical material was carried out. The method of the component analysis was used for differential study of the levels of the semantics of words. With a view to identifying the features of mentality of the Tatars in the use of a particular lexical unit a synthesis of techniques of cognitive and linguoculturological methods was applied.

\section{Results and discussion}

The language used by a person both captures the world and interprets the captured. In this process of interpreting, a person faces the emotional component. In the range of means of verbalization of emotions, a special place belongs to phraseological units. Complementing the denotational semantics, the emotional aspect of the phraseological units expresses the attitude of the subject to the object and transmits various emotions. The studied phraseological units of the theme group "anger" mostly appeal to the negative appraising emotions. They express disapproval or disparagement towards subjects or events.

The society assesses the character and behavior of its members on the basis of their definite features or behavior manifested in their livelihood. This is particularly evident in human emotions.

The denotative semantics of the phraseological units of the theme group "anger" can be defined as the state of the subject when the subject feels indignation, anger, and bitterness, when he is not able to control his actions. The basis of this group comprises the phraseological units 
with the component achu 'anger, malice, rage', expressing the negative attitude to the subject in question: achu yotu «swallow the anger»; achu totu «hold the anger». Both phrases have the meaning 'to bear a grudge'.

The two-volume publication by Naqi Isanbet "Phraseological Dictionary of the Tatar Language" (ISANBET, 1990). provides 25 articles with the mentioned lexeme, expressing negative semantics and various degrees of appraisal. For example, the emotional component of the phrase achu totu represent the minimal intensity, and the phrase achudan kara yanu «to become black of anger» with the meaning 'to blaze with anger' expresses the most intensive degree of the emotional state. It should be noted, that one of the main ethno-psychologic characteristics of the Tatar people is their patience, concealing their emotional state. Condemnation and criticism of parading the feelings are reflected both in the national oral tradition and in the lexical units. This feature is the basis of the ethnopedagogy, and the phraseological units with the lexeme achu 'anger, malice, rage' reveal this feature: all the phrases with this component studied by us express the subject's negative emotional state mainly hidden inside.

The emotional and appraisal attitude can vary depending on whether the speech concerns the third person or it is addressed to an interlocutor or else it is a statement of the person speaking about himself. It mostly concerns the cases of the verb-nominal phraseological units acting as predicates. The following phraseological units with the meaning "anger" are listed depending on the increase of intensity of the emotional state. For example, the phrase sul ayagy belän toru «to get up by the left leg» in the meaning 'to be in a dark mood, to be annoyed' is used towards a third person. The cultural-connotative semantics of this phrase is connected with the superstitions of the Tatars that if all the doings are made with the right hand, if in the morning a person gets up with the right leg, all the day will be easy and relaxed. But if a person derogates from that superstition, he will not find any luck in anything. This phraseological unit is used towards a person whose actions go beyond generally accepted norms.

The phraseological units üzen-üze beleshmäü; chygyrynnan chygu 'out of control', 'in a highly agitated mental state, quite angry' are mainly the speaker's statements about himself, or a little rarer - the description of the emotional state of a third person.

The phrases kyzu kul astyna tury kilü; kyzgan chakka tury kilü 'in the heat of the moment, when one is angry' are used to appraise the state of excitement, irritation and anger. The phraseological meaning of the mentioned phrases results from the lexeme kyzu (derivative - kyzgan) 'hot', which transmits the view of the state of some object or a phenomenon. The denotative semantics of the given word contributes to reveal the substantive relation of the sign 
enabling a substantive view. The significative component determines the correlation of the mentioned phrases to the view of the attribute and is more abstractive. The denotative and the significative components interact and form a unique substantive logical content of the phraseological units. The connotative component, which is the most important of all of the components in the semantic structure of phraseological units, stimulates the high intensity of the degree of the attribute (kyzu, kyzgan 'hot'), evokes the cause-and-effect associations and demonstrates a higher degree of denomination of anger.

The highest degree of the analyzed negative emotional state is represented by the phraseological units avyzynnan ut chächü «to disgorge fire out of the mouth» in the meaning 'to be on the rampage'; kük kebek kükräp, yashen kebek atu «to growl like thunder, to flash like lightning» in the meaning 'to speak angrily, in an irritated manner'; džene kuzgalu «shaitan (devil) bothers» in the meaning 'in a state of high emotion, indignation, dudgeon'; džene kotyra «the devil is in and is indignant», in the meaning 'to be beside oneself with rage'. The latter two phrases are directly related to the superstitions of the Tatar people who believed in the past that the evil spirits (džen - shaitan, devil) drive the people and make them nervous, upset, angry, and unable to control themselves, their emotions and actions.

Among the national-specific phraseological units connected with the culture of the Tatar people there are examples with the image of the eastern man whose moustache raise in anger: myegy ürä tora «his moustache raise», myegy tyrpayu «his moustache stick out» and others.

The language also possesses specific phraseological units - taboo in the form of blistering condemnations, remarks or whole statements with a strongly pronounced offensive or contemptuous connotative meaning, for example, vot tibä raz «here you one» in the meaning 'there you are!', lägnät töshsen / lägnät suksyn / lägnät sukkyry / lägnät töshkere / lägnät yaugyry, bashy betkere «damn you!»; bugazyna söyak kadalgyry, bashyna bulgyry «the devil take him!» and others.

\section{Summary}

The phraseological emotional view of the world in the Tatar language is more colorful than the nominative lexical view of the world due to the fact that phraseological units express the human emotions through numerous semantic models based on the figurative component of phrases.

This article presented the analysis of the phraseological units of the theme group "anger" expressing human negative emotions. According to the materials, the phraseological units of 
the studied group reveal the high degree of complexity of the designated emotions, which is witnessed by the definitions of the words denoting the state. It is to be noted, that the denotative semantics of the phraseological units of the theme group "anger" can be defined as the subject's state in which he is overtaken by the negative emotions, becomes indignant and bitter, unable to control his actions.

\section{Conclusion}

The phraseological units with the meaning "anger" represent lexically, semantically, emotionally and appraisingly a quite diverse group of emotional vocabulary with negative connotation. As the analysis reveals, emotionally appraising content of the studied phrases can vary depending on the subject's emotional condition and his attitude towards the addressee, and can be complemented by new emotionally appraising semes according to the specificity of the ethno-psychology of the language person. The cultural-connotative semantics of the phraseological units is closely related to the Tatar people's worldview which has formed and has been enriched throughout the life experience.

ACKNOWLEDGEMENTS: The work is performed according to the Russian Government Program of Competitive Growth of Kazan Federal University.

\section{REFERENCES}

ABDRAKHMANOVA, A.; GALIULLINA, G.; KHADIEVA, G. Names of tatar brands as the reflection of national mentality. Turkish Online Journal of Design Art and Communication, v. 7, p. 1122-1127, 2017.

BAYRAMOVA, L. Happiness and unhappiness as value and anti-value in the phraseologic paradigm of russian, tatar, english, german, french: axiological phraseological dictionary. Kazan: Center of Innovative Technologies Publ., 2012. 495 p.

GABBASOVA, G. Means of Expressivity in the Tatar Literature Language (a case study of nouns and adjectives). 2002. $26 \mathrm{f}$. Thesis (PhD) - UFA, 2002.

GALIEVA, N. GALIULLINA, G. Emotive idioms Tatar language as national mentality reflection. Journal of Language and Literature, v. 6, n. 1, p. 273-276, 2015.

GALIULLINA, G.; YUSUPOVA, A.; KHADIEVA, G.; DENMUKHAMETOVA, E. Turkotatar vocabulary as cognitive mapping of the national mentality. Kazan, 2001. 120 p. 
GIZATULLINA, A. Emotive sentences with abriged syntax structure in tatar and french. 2001. 2019 f. Thesis (PhD) - Kazan Federal University, Kazan, 2001.

ISANBET, N. Phraseological dictionary of the tatar language. Kazan, 1989. v. 2, 222 p.

KUZMINA, K. H.; KHADIEVA, G.; GALIULLINA, G. The history of the development of literary tatar language in the 20th century (based on the example of the language of literary works). Journal of Research in Applied Linguistics, v. 10, p. 592-599, 2019.

SHCHERBININA, T.; DENMUKHAMETOVA, E.; DENMUKHAMETOV, R. Landscape components during phraseologism in the Tatar language. Journal of Language and Literature, v. 2, n. 7, p. 353-356, 2016.

VAKHITOVA, D. Invective Vocabulary of the tatar language: the functional and ethnomental aspects. 2013. 239 f. Thesis (PhD) - Kazan Federal University, Kazan, 2013.

YERBULATOVA, I.; KIRILLOVA, Z.; SAHIN, L. "National and Cultural Realias of Translations into Tatar. Humanities and Social Sciences Reviews, v. 7, n. 6, p. 984-987, 2019.

ZAKIEV, M. Tatar lexicology. Kazan: Tahsi Publ, 2015. v. 1, 352 p.

ZAMALETDINOV, R. Tatar Linguoculturology: concepts of the mental world of a human. Kazan: Brig Publ., 2012. 300 p.

\section{How to reference this article}

GALIULLINA, G. R.; KHADIEVA, G. K.; MUKHAMETGALIEVA, Z. M.; DUBROVINA, M. E. Phraseological units as means of expressing the emotivity in the Tatar language. Rev. EntreLínguas, Araraquara, v. 7, n. esp. 1, p. 154-161, fev. 2021. e-ISSN: 2447-3529. DOI: https://doi.org/10.29051/el.v7iEsp1.14882

Submitted: $28 / 10 / 2020$

Required revisions: 19/12/2020

Approved: $13 / 01 / 2021$

Published: 28/02/2021 